\title{
Localization of Chitin Synthase in Mucor rouxii by an Autoradiographic Method
}

\author{
By RAFAEL SENTANDREU, ${ }^{1}$ AMELIA MARTINEZ-RAMON ${ }^{2}$ AND \\ JOSE RUIZ-HERRERA ${ }^{3 *}$ \\ ${ }^{1}$ Departamento de Microbiologia, Facultad de Farmacia, Universidad de Valencia, Spain \\ ${ }^{2}$ Instituto de Investigaciones Citológicas de la Caja de Ahorros de Valencia, Spain \\ ${ }^{3}$ Departamento de Genética y Biología Molecular del Centro de Investigación y Estudios \\ Avanzados del IPN, and Instituto de Investigación en Biología Experimental, Facultad de \\ Quimica, Universidad de Guanajuato, México
}

(Received 26 October 1983)

The localization of chitin synthase in the cells of Mucor rouxii was studied by a method which combined permeabilization of the cells with toluene/ethanol and incubation with the radioactive substrate UDP- $\left[{ }^{3} \mathrm{H}\right]$ Glc NAc followed by high resolution autoradiography. By this technique it was demonstrated that most of the chitin synthesized by these cells was located within the cytoplasm, and only a small amount of the enzyme product appeared at the cell surface. It was concluded that most of the chitin synthase of $M$. rouxii is located in the cytoplasm of the cells.

\section{INTRODUCTION}

Chitin, a linear $(1 \rightarrow 4)$ - $\beta$ - $N$-acetylglucosaminyl polymer, is a major fibrillar component of most fungal cells, where it is responsible for the shape and rigidity of their cell walls. Synthesis of chitin has been carried out in vitro by subcellular preparations obtained from different species of fungi (for a review, see Ruiz-Herrera, 1982). One aspect of chitin biosynthesis that has remained controversial is the subcellular distribution of the enzyme system involved. It has been reported that almost all the enzyme activity in protoplasts from Saccharomyces (Duran et al., 1975) and Candida albicans (Braun \& Calderone, 1978) was bound to the plasma membrane, and Vermeulen et al. (1979) reported that in protoplasts from Schizophyllum commune $50 \%$ of the enzyme activity was associated with the plasma membrane and about $30 \%$ was sedimented as a system of particles by high-speed centrifugation. In contrast, Bracker et al. (1976), Ruiz-Herrera et al. (1977) and Bartnicki-Garcia et al. (1978) isolated most of the chitin synthase from different fungi in the form of cytoplasmic microvesicular organelles (chitosomes) and demonstrated that these organelles were capable of forming chitin microfibrils in vitro. Previous work (Sentandreu \& Ruiz-Herrera, 1978; Dominguez et al., 1980; Flores-Carreon et al., 1980) demonstrated that chitin synthase could be detected in situ by permeabilization of fungal cells with small amounts of toluene/ethanol, a method originally introduced for the assay of cytoplasmic enzymes in whole cells (Reeves \& Sols, 1973; Serrano et al., 1973). In the present work we employed this technique of cell permeabilization in combination with high-resolution autoradiography to study the cellular localization of chitin synthase in Mucor rouxii. We present evidence that supports a cytoplasmic location of the enzyme.

\section{METHODS}

Organism and culture conditions. Mucor rouxii IM-80 (A TCC 24905) was used in this study. Spores $\left(2 \times 10^{8}\right)$ were inoculated into $200 \mathrm{ml}$ of liquid complex (YPG) medium (Bartnicki-Garcia \& Nickerson, 1962) and incubated with shaking at $28^{\circ} \mathrm{C}$. After about $6 \mathrm{~h}$, germlings were collected by low-speed centrifugation, washed with chilled $0.05 \mathrm{M}-\mathrm{KH}_{2} \mathrm{PO}_{4} / \mathrm{NaOH}$ (phosphate) buffer $\mathrm{pH} 6.5$ containing $10 \mathrm{mM}-\mathrm{MgCl}_{2}$ and finally resuspended in $10 \mathrm{ml}$ of the same buffer. 
Cell permeabilization. The cells were mixed with an ethanol/toluene mixture $(50 \%, \mathrm{v} / \mathrm{v})$ to give a final concentration of $1 \%(\mathrm{v} / \mathrm{v})$. This suspension was subjected to Vortex mixing for ten $30 \mathrm{~s}$ periods, with 2 min intervals of cooling in an ice bath. The cells were then washed five times with cold buffer and finally resuspended in $4 \mathrm{ml}$ of buffer.

Chitin synthase assays. The chitin synthase activity of permeabilized cells was measured essentially as previously described (Sentandreu \& Ruiz-Herrera, 1978; Flores-Carreon et al., 1980). Reaction mixtures contained: $0.5 \mathrm{~mm}$ uridine $5^{\prime}$-diphosphate $N$-acetyl-D- $\left[{ }^{14} \mathrm{C}\right]$ glucosamine (UDP-[ $\left[{ }^{14} \mathrm{C}\right] \mathrm{GlcNAc}$ ) (sp. act. $0.163 \mathrm{Ci} \mathrm{mol}^{-1} ; 6.03 \mathrm{GBq}$ $\mathrm{mol}^{-1}$ ), $0.2 \mathrm{mM}$-ATP, $20 \mathrm{~mm}-\mathrm{N}$-acetylglucosamine (GlcNAc), $10 \mathrm{mM}-\mathrm{MgCl}_{2}, 0.5 \mathrm{M}$-phosphate buffer $\mathrm{pH} 6.5$ and permeabilized cells in a final volume of $125 \mu \mathrm{l}$. Chitin synthase was normally activated by the addition of either trypsin $\left(1 \mathrm{mg} \mathrm{ml}^{-1}\right)$ or rennilase $(3 \mathrm{mg} \mathrm{ml}-1)$. Samples were incubated at $22{ }^{\circ} \mathrm{C}$ for various periods. The reaction was stopped by the addition of either $2-3$ drops of glacial acetic acid or $0.5 \mathrm{ml} 2 \%(\mathrm{v} / \mathrm{v})$ glutaraldehyde in $0.1 \mathrm{M}-$ cacodylate buffer $\mathrm{pH} 7 \cdot 1$. Samples were filtered through a fibreglass filter (Schleicher \& Schull no. 8, Dassel, FRG) and washed five times with $20 \mathrm{ml}$ each of $1 \mathrm{M}$-acetic acid/ethanol $(70: 30, \mathrm{v} / \mathrm{v})$, or, after overnight incubation, with $5 \mathrm{ml} 2 \%$ glutaraldehyde followed by five washings with $20 \mathrm{ml}$ each of $0.5 \mathrm{M}$-Tris buffer $\mathrm{pH} 7.0$ containing $10 \mathrm{mM}$ $\mathrm{MgCl}_{2}$. The filters were dried and radioactivity was counted with a scintillation spectrometer.

Preparation of samples for autoradiography. Samples $(2 \mathrm{ml})$ of toluenized cells were incubated at room temperature for $60 \mathrm{~min}$ in reaction mixtures containing : $0.05 \mathrm{M}$-phosphate buffer $\mathrm{pH} 6.5,10 \mathrm{mM}-\mathrm{MgCl}_{2}, 40 \mathrm{~mm}-\mathrm{GlcNAc}$ and $2 \mathrm{mM}-\mathrm{UDP}\left[{ }^{3} \mathrm{H}\right] \mathrm{GlcNAc}\left[10 \mathrm{Ci} \mathrm{mol}^{-1}\left(370 \mathrm{GBq} \mathrm{mol}^{-1}\right) ; 20 \mu \mathrm{Ci} \mathrm{ml}^{-1}\left(740 \mathrm{kBq} \mathrm{ml}^{-1}\right)\right]$. One sample received $1 \mathrm{mg}$ trypsin $\mathrm{ml}^{-1}$ to activate the chitin synthase zymogen. Incorporation was stopped by the addition of $20 \mathrm{ml} 2 \%$ glutaraldehyde in $0.1 \mathrm{M}$-cacodylate buffer $\mathrm{pH} 7 \cdot 1$ and samples were treated as described below.

Electron microscopy. Cells were fixed overnight in $2 \%$ glutaraldehyde in $0.1 \mathrm{M}$-cacodylate buffer $\mathrm{pH} 7 \cdot 1$ at $0^{\circ} \mathrm{C}$, washed four times with $50 \mathrm{~mm}$-Tris buffer $\mathrm{pH} 7.0$ containing $10 \mathrm{mM}-\mathrm{MgCl}_{2}$, and embedded in Araldite resin. The technique used for autoradiography has been previously described (Martinez-Ramon et al., 1975). Thin sections $(80 \mathrm{~nm})$ were collected over celloidine film $(2 \%$, w/v, in isoamyl acetate). The dry sections were stained with $5 \%$ $(\mathrm{w} / \mathrm{v})$ uranyl acetate in water for $1 \mathrm{~h}$ and finally coated with a carbon film about $10 \mathrm{~nm}$ thick. The nuclear emulsion used was Ilford L4 diluted to $1 / 4$ strength $(\mathrm{v} / \mathrm{v})$, and the exposure time was 4 weeks at $4^{\circ} \mathrm{C}$. The silver grains were developed with ascorbic acid/fenidon after previous treatment for $30 \mathrm{sec}$ with a solution containing $\left(\mathrm{ml}^{-1}\right)$ : $0.04 \mathrm{mg} \mathrm{AuCl}_{3}, 0.5 \mathrm{mg} \mathrm{KSCN}$ and $0.5 \mathrm{mg} \mathrm{KBr}$. Finally the sections were contrasted with lead citrate and examined and photographed with a Philips 300 electron microscope.

Quantitative autoradiography. Photographs of the cell cross-sections were divided into three domains: (1) external, an area $500 \mathrm{~nm}$ wide immediately external to the cell wall; (2) cortical, a similar area from the external limit of the wall toward the interior of the cell, i.e. embracing the cell envelope; and (3) the remainder of cytoplasm of the cell. The numbers of silver grains in each domain were recorded for 30 cell cross-sections, and the total crosssectional area was determined by a photogravimetric method. Results were expressed as total and specific activity. Specific activity was expressed as the number of silver grains per $100 \mu \mathrm{m}^{2}$. The significance of the results was analysed by the method of Whur et al. (1969), where the percentage of total silver grains is calculated for each domain. This value corresponds to the 'uncorrected grain distribution'. The method eliminates non-significant grains by subtracting the percentage value of the surface corresponding to each domain from the percentage of grains found in the equivalent domain. These calculated values, designated 'corrected grain distribution', are considered significant only if they show positive values.

Miscellaneous. UDP-GlcNAc was from Sigma; UDP- $\left[{ }^{14} \mathrm{C}\right] \mathrm{GlcNAc}$ was from Amersham. Polyoxin D was obtained from S. Bartnicki-Garcia, University of California, Riverside, USA, through the courtesy of M. Sakamaki, Kaken Chemical Co. (Tokyo, Japan). A mixture of nikkomycins $X$ and $Z$ was a generous gift from $\mathrm{H}$. Zahner, University of Tübingen, FRG. Rennilase, an acid protease from Mucor miehei, was a gift from Novo Enzyme Corporation (Mamaroneck, NY, USA).

\section{RESULTS}

As described previously (Sentandreu \& Ruiz-Herrera, 1978), intact germlings of $M$. rouxii incubated with labelled UDP-GlcNAc did not synthesize chitin in significant amounts, whereas those treated with toluene incorporated the label in amounts that increased in proportion to the incubation time. The addition of an activating protease increased chitin synthesis, but contrary to results obtained with cell-free extracts or purified chitosomes (Ruiz-Herrera \& BartnickiGarcia, 1976; Ruiz-Herrera et al., 1977), trypsin was more effective as an activator than rennilase (Fig. 1). Probably the larger molecular weight of the latter impairs its penetration through the cell wall. Polyoxin and nikkomycin almost completely inhibited GlcNAc incorporation by permeabilized cells (Fig. 1). The lower inhibitory effect of polyoxin was possibly due to the fact that the sample used had been kept for several years in the freezer and may have lost some of its potency. 


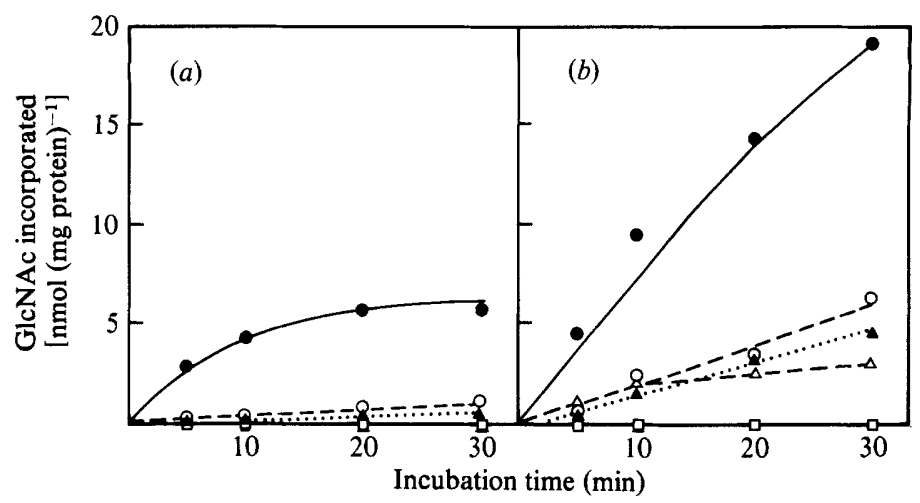

Fig. 1. Chitin biosynthesis by permeabilized cells of Mucor rouxii. Effect of protease treatment and addition of inhibitors. Germinating spores treated with toluene/ethanol were incubated with substrate and additions as described in Methods. At intervals, samples were removed, the reaction was stopped, the cells were filtered, washed and dried, and radioactivity incorporated was measured. $(a)$ Cells incubated with rennilase. (b) Cells incubated with trypsin. $\bigcirc$, No inhibitor added; $\bigcirc$, plus $20 \mu \mathrm{M}$-polyoxin; $\boldsymbol{\Delta}$, plus $5 \mu \mathrm{M}$-nikkomycin; $\square$, plus $20 \mu \mathrm{M}$-nikkomycin; $\Delta$, no protease added.

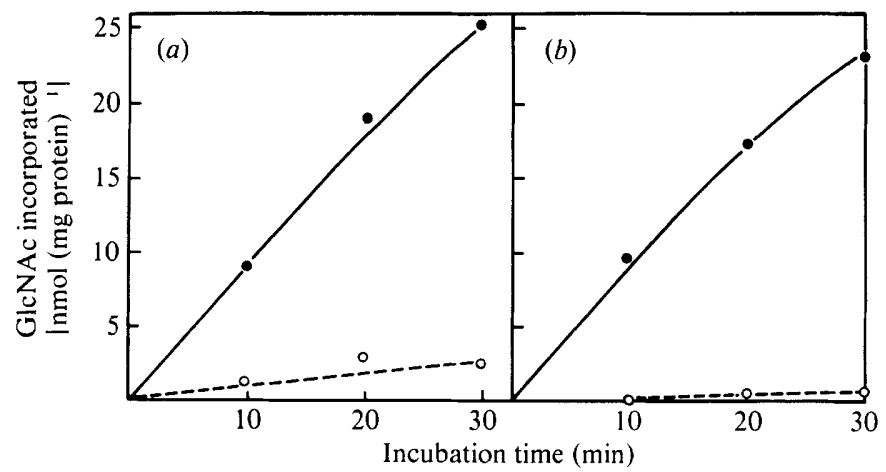

Fig. 2. Efficiency of washing for the removal of soluble radioactive compounds from permeabilized cells. Germinating spores were treated and incubated as described for Fig. 1. (a) The reaction was stopped with glacial acetic acid and the cells washed with acetic acid/ethanol. $(b)$ The reaction was stopped with glutaraldehyde and the cells washed with glutaraldehyde and Tris buffer. $\bigcirc$, No inhibitor added; $O$, plus $5 \mu \mathrm{M}$-nikkomycin.

Incubated cells washed with either acetic acid/ethanol or Tris buffer after fixation with glutaraldehyde (see Methods) gave similar results for radiolabel incorporation (Fig. 2). No significant incorporation was observed in either case when nikkomycin was present in the incubation media. These results show that all free substrate and soluble by-products were effectively extracted from the permeabilized cells during washings, with only chitin remaining in the washed cells.

Toluene-treated germinating spores incubated for $60 \mathrm{~min}$ with UDP- $\left[{ }^{3} \mathrm{H}\right] \mathrm{GlcN}$ Ac under the conditions described in Methods were fixed and prepared for autoradiography. Figs 3 and 4 are representative electron micrographs of these cells. Germ tubes are recognizable by their wall being thinner than those of the spores. With regard to silver grain distribution, several observations may be pointed out : firstly, extracellular background is very low, only a few grains appearing distant from the cells; secondly, most grains appear in the interior of the cells; thirdly, grain distribution is not homogeneous, since grains appear distinctly clustered; and finally, grains are not preferentially located in the growing region of the germlings but appear randomly distributed in the cells. No significant difference in the grain distribution was observed between the cells incubated in the presence of trypsin and those incubated in its absence, although grains in the former were more abundant (see below). 


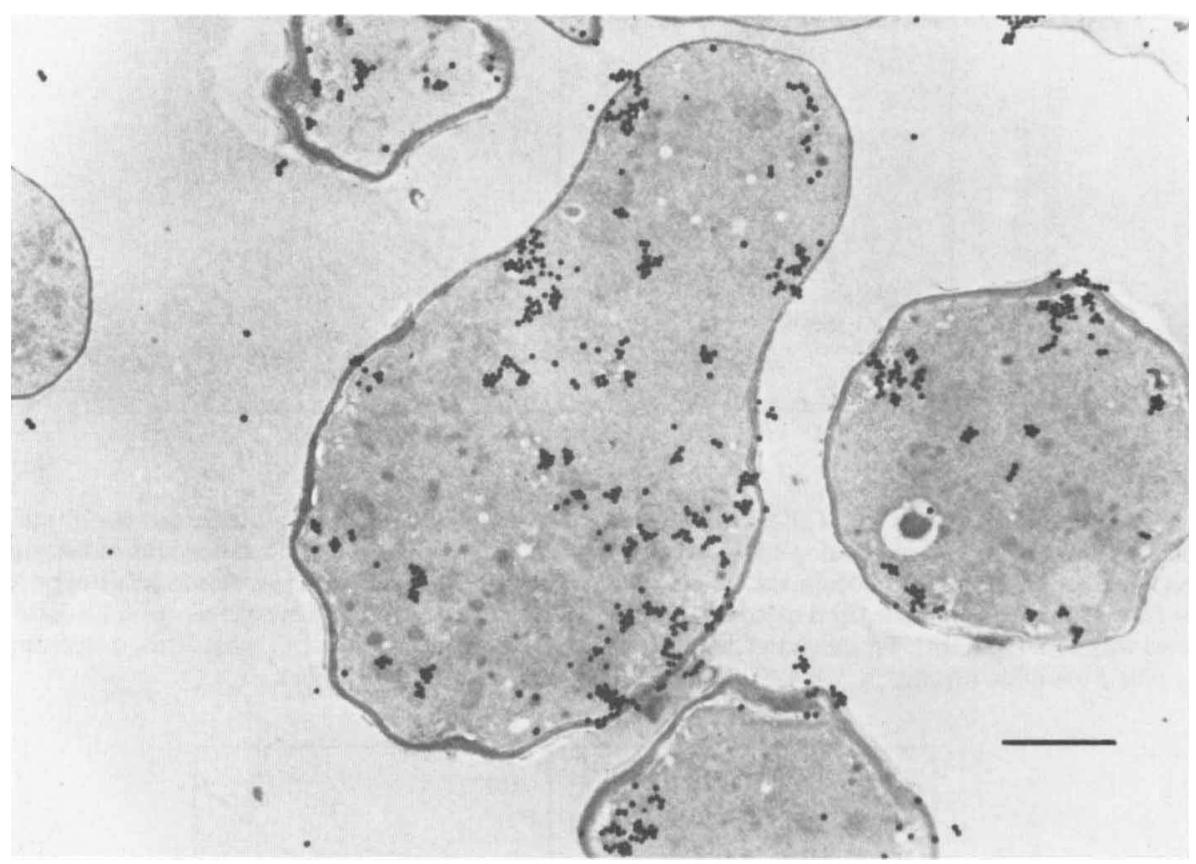

Fig. 3. Electron micrograph showing a typical field of cells of $M$. rouxii incubated with UDP$\left[{ }^{3} \mathrm{H}\right] \mathrm{GlcN} A \mathrm{c}$ in the presence of trypsin and developed for autoradiography. Notice the low background number of grains and their accumulation in the cytoplasm of the cells. Bar marker, $2 \mu \mathrm{m}$.

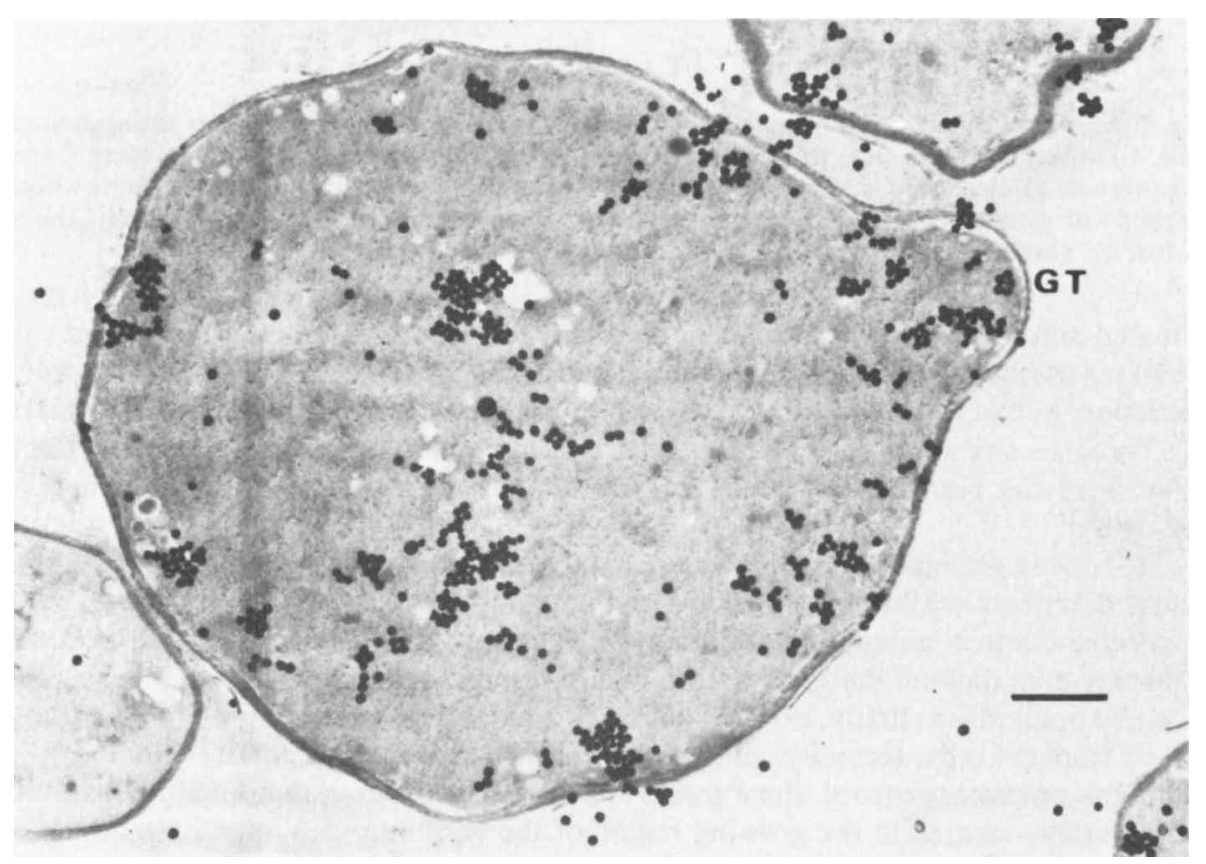

Fig. 4. A cell of $M$. rouxii showing the accumulation of grains in the internal zone of the cell. This cell was incubated with labelled substrate in the presence of trypsin. GT, germ tube; notice the thinner cell wall. Bar marker, $1 \mu \mathrm{m}$. 
Table 1. Silver grain distribution within cross-sections of Mucor rouxii

$\begin{array}{clcc}\text { Zone* } & \text { Parametert } & \text { Control cells } & \begin{array}{c}\text { Trypsin- } \\ \text { treated cells }\end{array} \\ \text { External }(500 \mathrm{~nm} \text { band) } & \text { Total activity } & 217 & 654 \\ & \text { Area }\left(\mu \mathrm{m}^{2}\right) & 403 & 448 \\ & \text { Specific activity } & 53.8 & 145 \cdot 9 \\ \text { Cortical (500 nm band) } & \text { Total activity } & 482 & 2407 \\ & \text { Area }\left(\mu \mathrm{m}^{2}\right) & 397 & 440 \\ & \text { Specific activity } & 121 \cdot 4 & 547 \cdot 0 \\ \text { Remainder of cytoplasm } & \text { Total } & 1912 & 7263 \\ & \text { Area }\left(\mu \mathrm{m}^{2}\right) & 1560 & 1838 \\ & \text { Specific activity } & 122.5 & 392 \cdot 2\end{array}$

* For description of zones see Methods.

$\dagger$ Total activity is defined as the number of silver grains in 30 cell cross-sections, and specific activity as the number of silver grains per $100 \mu \mathrm{m}^{2}$.

Table 2. Analysis of the significance of the distribution of silver grains within cross-sections of Mucor rouxii

\begin{tabular}{|c|c|c|c|c|c|c|}
\hline \multirow[b]{2}{*}{ Zone $^{*}$} & \multicolumn{2}{|c|}{ Uncorrected activity ( $\%$ ) } & \multicolumn{2}{|c|}{ Surface $(\%)$} & \multicolumn{2}{|c|}{ Corrected activity $\dagger$} \\
\hline & Control & + Trypsin & Control & + Trypsin & Control & + Trypsin \\
\hline External & $8 \cdot 31$ & $6 \cdot 33$ & $17 \cdot 07$ & 16.43 & $-8 \cdot 76$ & $-10 \cdot 10$ \\
\hline Cortical & $18 \cdot 46$ & $23 \cdot 30$ & $16 \cdot 82$ & $16 \cdot 14$ & 1.64 & $7 \cdot 16$ \\
\hline Remainder of cytoplasm & $73 \cdot 32$ & $70 \cdot 31$ & $66 \cdot 10$ & 67.42 & $7 \cdot 12$ & $2 \cdot 89$ \\
\hline
\end{tabular}

* For description of zones see Methods.

$\dagger$ Calculated as described in Methods; positive values are considered to be significant.

Quantitative evaluation of the silver grain distribution is shown in Table 1. It may be observed that most of the radioactivity was present in the interior of the cells, whereas the external zone contained less radioactivity. In cells incubated with trypsin, radioactivity increased in the three zones by the following factors : $2 \cdot 71$ for the external zone, 4.50 for the cortical zone and $3 \cdot 22$ for the intracellular zone. Specific activity was similar for the cortical and internal zones, although trypsin-treated cells had a higher specific activity in the cortical zone. The specific activity of the external zone was about one third of the internal radioactivity.

The significance of the silver grain distribution results was analysed as described in Methods. Only the activity found inside the cells was significant; the values found external to the cell wall were not significant (Table 2).

\section{DISCUSSION}

Some of the previous techniques used for determination of chitin synthase localization introduce, in our opinion, artefacts that limit the value of the results. In particular, the preparation of protoplasts involves lengthy and aggressive treatment. Therefore profound structural and metabolic alterations may occur as suggested by the extreme lability of apical vesicles to changes in the environment (Girbardt, 1957), and the fact that yeast protoplasts show a lag of 60-90 min before reinitiation of protein synthesis under optimal growth conditions (R. Sentandreu, unpublished observations). On the other hand, mechanical breakage of the cells may destroy the integrity of membranes and other labile structures. For this reason cytoplasmic localization of chitin synthase has been assessed by the use of other techniques for cell breakage, e.g. osmotic shock of the wall-less mutant of Neurospora crassa (Bartnicki-Garcia et al., 1980) and removal of cytoplasmic material from the tip of Phycomyces blakesleeanus sporangiophores by use of a microsyringe (Herrera-Estrella et al., 1982).

To avoid some of the above-mentioned problems we have used a cell permeabilization method that causes a rapid halt in cell metabolism. Treatment of cells with small amounts of 
toluene/ethanol produces an outflow of ions and other small metabolites, but labile enzyme systems such as glucan synthase (Sentandreu et al., 1975), chitin synthase (Sentandreu \& RuizHerrera, 1978; Flores-Carreon et al., 1980) in whole cells, and even chitin synthase in isolated chitosomes (S. Bartnicki-Garcia \& R. Sentandreu, unpublished observations) remain fully active. These results stress the non-destructive character of the technique used.

Incubation of these permeabilized cells with the sugar-nucleotide substrate for chitin biosynthesis leads to accumulation of the insoluble product in the vicinity of the enzyme, since all the normal delivery mechanisms of the cell are disrupted. Autoradiography of these cells thus permits the localization of chitin synthase in the cell. The removal of residual substrate and soluble by-products from glutaraldehyde-fixed cells by washing with buffer is evidence that the only remaining radioactivity derives from an insoluble product, which is considered to be chitin by two observations: its amount is increased by proteolysis, and its accumulation is almost abolished by the chitin synthase inhibitors polyoxin and nikkomycin.

The results obtained establish that most of the chitin synthesized by permeabilized cells is located in the cytoplasm. According to quantitative autoradiography data from Salpeter $e t$ al. (1969) we calculated that an area $500 \mathrm{~nm}$ wide on each side of the cell surface would register about $80 \%$ of the radioactivity originating from a source located in the plasma membrane and/or the cell wall. [The cell wall of the spore is $100-160 \mathrm{~nm}$ thick and that of the germ tube $40-60 \mathrm{~nm}$ thick (Bartnicki-Garcia et al., 1968)]. Therefore it would be expected that, statistically, grain distribution would be equal at both sides of the cell surface. This was not the case, and in fact the amount of grains located external to the cells was statistically not significant. This means that most of the grains in the cortical zone came from internal sources. A word of caution must be raised however. Although non-significant (negative) values were obtained for the external zone, its specific activity increased after trypsin treatment. This result suggests that some (although very low) activity of chitin synthase may be located at the cell surface. The fact that the specific activities of the cortical and internal zones are about the same suggests that they do not represent significantly different enzyme compartments. Active chitin synthase detected in the cytoplasm of cells incubated without trypsin may represent either enzyme activated during the treatment with toluene or active molecules in transit to their final destination at the cell surface.

In conclusion, the results reported in this paper support and extend previous observations that showed that chitin synthase in $M$. rouxii is localized mostly in the cytoplasm.

This work was supported in part by grants $(4593-1980 ; 120-1982)$ from the Comisión Asesora de Investigación Científica y Técnica, Spain, the Consejo Superior de Investigación Científica, Spain; the PNCB of the Consejo Nacional de Ciencia y Tecnología, México; and The Dirección General de Investigación Científica y Superación Académica of the Subsecretaria de Educación Superior e Investigación Científica, SEP, México.

Thanks are given to Georgina Reyna and Mireya Tijerina for their valuable assistance in some experiments.

\section{REFERENCES}

BARTNICKI-GARCIA, S. \& Nickerson, W. J. (1962). Induction of yeast-like development in Mucor by carbon dioxide. Journal of Bacteriology 84, 829-840.

Bartnicki-Garcia, S., Nelson, N. \& Cota-Robles, E. (1968). Electron microscopy of spore germination and cell wall formation in Mucor rouxii. Archiv für Mikrobiologie 63, 242-255.

Bartnicki-Garcia, S., Bracker, C. E., Reyes, E. \& RUIZ-HERRERA, J. (1978). Isolation of chitosomes from taxonomically diverse fungi and synthesis of chitin microfibrils in vitro. Experimental Mycology 2, 173-192.

Bartnicki-Garcia, S., Bracker, C. E. \& RuizHerrera, J. (1980). Isolation of chitosomes from osmotically fragile cells of Mucor rouxii and Neurospora crassa. Abstracts of the 80th Annual Meeting of the American Society for Microbiology, p. 98.
Bracker, C, E., Ruiz-Herrera, J. \& BartnickiGARCIA, S. (1976). Structure and transformation of chitin synthetase particles (chitosomes) during microfibril synthesis in vitro. Proceedings of the National Academy of Sciences of the United States of America 73, 4570-4574.

Braun, P. C. \& Calderone, R. A. (1978). Chitin synthesis in Candida albicans: comparison of yeast and hyphal forms. Journal of Bacteriology 135, 14721477.

Dominguez, A., Elorza, M. V., Villanueva, J. R. \& SENTANDREU, R. (1980). Regulation of chitin synthetase in Saccharomyces cerevisiae: effect of the inhibition of cell division and of synthesis of RNA and protein. Current Microbiology 3, 263-266.

Duran, A., Bowers, B. \& Cabib, E. (1975). Chitin synthetase zymogen is attached to the yeast plasma 
membrane. Proceedings of the National Academy of Sciences of the United States of America 72, 39523955.

Flores-Carreon, A., Larriba, G. \& Sentandreu, R. (1980). Stabilization of chitin synthetase of Mucor rouxii and detection of two zymogenic pools. FEMS Microbiology Letters 8, 151-155.

Girbardr, M. (1957). Der Spitzenkörper von Polystictus versicolor. Planta 50, 47-59.

Herrera-Estrella, L., Chavez, B. \& Ruiz-HerRERA, J. (1982). Presence of chitosomes in the cytoplasm of Phycomyces blakesleeanus and the synthesis of chitin microfibrils. Experimental Mycology 6, 385388.

Martinez-Ramon, A., Forteza-Bover, G., HernanDEZ YAGo, J. \& K NECHT, R. E. (1975). Autoradiografia y Ultraestructura Celular. Valencia: Editorial Facta.

ReEves, R. E. \& Sols, A. (1973). Regulation of Escherichia coli phosphofructokinase 'in situ'. Biochemical and Biophysical Research Communications 50, 459-466.

RUIZ-HERRERA, J. (1982). Synthesis of chitin microfibrils in vitro. In Cellulose and Other Natural Polymer Systems, pp. 207-223. Edited by R. M. Brown, Jr. New York: Plenum Press.

RUIZ-HERRERA, J., LoPEZ-Romero, E. \& BARTNICKIGARCIA, S. (1977). Properties of chitin synthetase in isolated chitosomes from yeast cells of Mucor rouxii. Journal of Biological Chemistry 252, 33383343.

Salpeter, M. M., Bachmann, L. \& Salpeter, E. E. (1969). Resolution in electron microscope autoradiography. Journal of Cell Biology 41, 1-20.

Sentandreu, R. \& Ruiz-HerRera, J. (1978) In situ study of the localization and regulation of chitin synthetase in Mucor rouxii. Current Microbiology 1, 7780.

Sentandreu, R., Elorza, M. V. \& Villanueva, J. R. (1975). Synthesis of yeast wall glucan. Journal of General Microbiology 90, 13-20.

Serrano, R., Gancedo, J. M. \& Gancedo, C. (1973). Assay of yeast enzymes 'in situ'. A potential tool in regulation studies. European Journal of Biochemistry 34, 479-482.

Vermeulen, C. A., Raeven, M. B. J. M. \& Wessels, J. G. H. (1979). Location of chitin synthetase activity in subcellular fractions of Schizophyllum commune protoplasts. Journal of General Microbiology 114, 8797.

Whur, P., Hesovics, A. \& Leblond, C. P. (1969). Radioautographic visualization of the incorporation of galactose $-\left[{ }^{3} \mathrm{H}\right]$ and mannose $-\left[{ }^{3} \mathrm{H}\right]$ by rat thyroids in vitro in relation to the stages of thyroglobulin synthesis. Journal of Cell Biology 43, 289-311. 